\title{
Phosphorus requirement and partitioning in oat cultivars
}

\author{
Jonas Manica $^{\text {* }}$ (D) Pedro Alexandre Varella Escosteguy ${ }^{2}$
}

\begin{abstract}
${ }^{1}$ Programa de Pós-graduação em Agronomia (PPGAgro), Universidade de Passo Fundo (UPF), 99052-900, Passo Fundo, RS, Brasil. E-mail: jonas_manica@hotmail.com. ${ }^{*}$ Corresponding author.

${ }^{2}$ Faculdade de Agronomia e Medicina Veterinária (PPGAgro),Universidade de Passo Fundo (UPF), Passo Fundo, RS, Brasil.
\end{abstract}

ABSTRACT: Maintenance fertilization changes with nutrient requirements and partitioning, but these are not well known for oat cultivars. The aim of this study was to evaluate whether phosphorus $(P)$ requirements and partitioning vary among cultivars of oat (Avena sativa L.). The UPFA 'Ouro', UPFPS 'Farroupilha', IPR 'Afrodite', URS 'FAPA Slava', 'Barbarasul', 'FAEM 007', URS 'Taura', and 'URS 21' were cultivated in a Latosol with high P content in a greenhouse in 2015. Plants were sampled at physiological maturity and divided into roots, stem, leaves, and grain tissues. Phosphorus content and the dry matter weight of these parts were evaluated and the uptake amount and partitioning of $P$ were estimated. The values of these variables differed across cultivars, except the $P$ content in the grain ('average', $\left.4.0 \mathrm{~g} P \mathrm{~kg}^{-1}\right)$. 'Afrodite' and 'FAPA Slava' have lower requirements and partitioning of $P$ in the grain, but these did not vary among the other cultivars. Requirements and partitioning of $P$ in stem and leaves increased in the following order: 'Ouro' and 'Farroupilha' $<$ 'Taura' and 'FAPA Slava'< 'URS 21'< 'Afrodite', 'Barbarasul' and 'FAEM 007'. Requirement and partitioning of $P$ in roots, stem, leaves, and grain differs across cultivars, which indicates that this factor, besides how the oat is used (such as for grain, pasture, silage, cover crop), can be used to improve maintenance fertilization.

Key words: avena sativa L., phosphate fertilization, maintenance fertilization.

Demanda e partição de fósforo em cultivares de aveia-branca

RESUMO: A adubação de reposição varia com a demanda e a partição de nutrientes, mas isso é pouco conhecido em relação as cultivares de aveia. $O$ estudo objetivou avaliar se a demanda e a partição de fósforo $(P)$ diferem entre cultivares de aveia-branca. As cultivares 'UPFA 'Ouro', 'UPFPS Farroupilha', 'IPR Afrodite', 'URS 21', 'URS FAPA Slava', 'Barbarasul', 'FAEM 007', 'URS Taura' e 'URS 21' foram cultivadas em um Latossolo com teor alto de P, em estufa agrícola, no ano de 2015. Na maturação fisiológica, as plantas foram fracionadas em raizes, colmo, folhas e grão e o teor de P e a massa seca desses órgãos foram avaliados, estimando-se a quantidade e a partição desse nutriente. $O$ valor dessas variáveis diferiu entre cultivares, exceto o teor de P do grão (média 4,0g $P \mathrm{~kg}^{-1}$ ). Nessa parte da planta, a demanda e a partição desse nutriente foi menor na 'Afrodite' e na 'FAPA Slava', não diferindo entre as demais cultivares. Na parte vegetativa (colmo + folhas), o valor dessas variáveis aumentou na seguinte ordem: 'Ouro'e 'Farroupilha'< 'Taura' e 'FAPA Slava'< 'URS 21'< 'Afrodite', 'Barbarasul'e 'FAEM 007'. A demanda e a partição de P em raizes, colmo, folhas e grão variam com a cultivar, indicando que esse fator, além da finalidade de uso da aveia-branca (grão, pastejo, silagem, cobertura do solo, etc) podem ser utilizados para melhorar a adubação de reposição.

Palavras-chave: avena sativa L., adubação fosfática, adubação de reposição.

Oat (Avena sativa L.) is one of the most cultivated Poaceae in the world and has numerous purposes including grain production, forage, hay, silage, soil coverage, and green manure. To maximize the potential yield of oat growing in tropical soils, phosphorus (P) fertilization is critical. Soils with low $\mathrm{P}$ content can be amended by corrective fertilization, which is complemented with the amount of $\mathrm{P}$ removed from the field at the harvested part of the crop (maintenance fertilization). These fertilization strategies contribute to avoid both $\mathrm{P}$ soil-test and the decline of subsequent crop yields. Maintenance fertilization is one critical factor to maintain high soil-P levels in high-yielding systems. It is based on the amount of $\mathrm{P}$ uptake by oat (extraction) and accumulates in the harvest and exported part from the field (grain, leaves, and stem on forages, or the whole plant on silage), which vary with the amount of dry matter production.

As $\mathrm{P}$ content and the amount of dry matter differ among parts of oat plants, Pup take requirements also vary among the plant organs. In southernmost Brazil, where oat production is predominant, the amount of $\mathrm{P}$ exported by the grain varied from 7.0 (BONA et al., 2016) to $9.0 \mathrm{~kg}$ of $\mathrm{P}_{2} \mathrm{O}_{5}$ $\mathrm{t}^{-1}$ (ESCOSTEGUY et al., 2014). For forage or hay production, oat removal rate fertilization is $10 \mathrm{~kg}$ $\mathrm{P}_{2} \mathrm{O}_{5} \mathrm{t}^{-1}$ (FIORIN \& LIMA, 2016). These amounts closely correlate to oat removal rate recommendations in other countries (NAKAGAWA et al., 2009; 
SORATTO \& CRUSCIOL, 2008; SILVA et al., 2015; PARK et al., 2016). Moreover, $16 \mathrm{~kg} \mathrm{P}_{2} \mathrm{O}_{5} \mathrm{t}^{-1}$ of grain has been reported by NAKAGAWA \& ROSOLEM (2005), which is overestimated compared to other studies cited above and technical indications. However, removal of $P$ has not been quantified across a range of oat cultivars or genotypes. Furthermore, genotypic variation for the partitioning of this nutrient has not been reported. Because these traits are affected by the environment, genotypes, yield range, and other grain yield-determining factors, the maintenance fertilization rate may need adjustment. This information is also important to confirm the current fertilization recommendations for oat because it has not changed since 2000 (CQFS-RS/SC, 2004). The objective of our study was; therefore, to evaluate whether P requirements and partitioning vary among cultivars of oat (Avena sativa L.).

The experiment was carried out at Universidade de Passo Fundo (UPF), Passo Fundo, Rio Grande do Sul, Brazil, from June to October 2015. The experimental units were 10 -L plastic pots containing $7.8 \mathrm{~kg}$ dried and sieved (6-mm sieve) soil, which were kept in a greenhouse with a plastic film roof and metal netting walls. Oat cultivars were grown in Rhodic Hapludox (USDA, 2014).The soil was collected in the $0-20 \mathrm{~cm}$ top-layer in a field cultivated with grain crops and managed with no tillage. Before the experiment, the soil was analyzed according to Tedesco et al. (1995); it contained $720.0 \mathrm{~g} \mathrm{~kg}^{-1}$ clay, $40.0 \mathrm{~g} \mathrm{~kg}^{-1}$ silt; $240.0 \mathrm{~g} \mathrm{~kg}^{-1}$ sand; was pH 5.8 in water; had an SMP Index score of 6.0; contained 9.6 and $219.0 \mathrm{mg} \mathrm{kg}^{-1}$, of extractable $\mathrm{P}$ and $\mathrm{K}$ (Mehlich-1), respectively, $42.0 \mathrm{~g} \mathrm{~kg}^{-1}$ of organic matter, $0.0,6.4$ and $2.7 \mathrm{cmol}_{\mathrm{c}} \mathrm{kg}^{-1}$, and $71.4 \mathrm{mg} \mathrm{kg}^{-1}$ of exchangeable $\mathrm{Al}, \mathrm{Ca}, \mathrm{Mg}$, and $\mathrm{Mn}\left(1.0 \mathrm{~mol} \mathrm{~L}^{-1} \mathrm{KCl}\right)$, respectively, and $4.4 \mathrm{cmol}_{\mathrm{c}} \mathrm{kg}^{-1}$ of $\mathrm{H}+\mathrm{Al}$ (potential acidity at $\mathrm{pH} 7.0$ ); had $69.0 \%$ of saturation by basic cations (V value) in the potential CEC; had available $\mathrm{S}^{-\mathrm{SO}_{4}}$ and B of 16 and $0.7 \mathrm{mg} \mathrm{kg}^{-1}$, respectively; and contained extractable $\mathrm{Zn}$ and $\mathrm{Cu}$ of 3.68 and $6.57 \mathrm{mg}$ $\mathrm{kg}^{-1}$, respectively. These values indicated high content of $\mathrm{P}_{-} \mathrm{PO}_{4}$ and other nutrients and no acidity limitation for white oat crop.

A completely randomized design was used. Treatments were tested with four replicates and comprised the following oat cultivars: UPFA 'Ouro', UPFPS 'Farroupilha', IPR 'Afrodite', URS 'Fapa Slava', 'Barbarasul', 'FAEM 007', URS 'Taura' and 'URS 21'. These cultivars are from different genealogies and are used in southern Brazil. Seeds were sown in experimental plots and after germination, 11 seedlings were kept per plot (equivalent to 300 plants $\mathrm{m}^{-2}$ ) until grain harvest. Soil moisture was maintained at $70 \%$ of the maximum water retention capacity. Procedures and plant care followed the Southern Brazil Guidelines for oat crops.

Total $P$ and dry matter content were assessed at full physiological maturity stage. The aboveground portion and the root system were sampled by cutting seven plants pot $^{-1} 2 \mathrm{~cm}$ above the soil surface. These samples were taken from the middle of the pot. The root samples were washed with water in a $315-\mu \mathrm{m}$ sieve to dislodge attached soil particles. Shoot (stem, leaves, and grain) and root samples were dried $\left(65^{\circ} \mathrm{C}\right)$ in a forced-air oven and the dry matter was weighted on a precision balance. After being ground to pass through a 2-mm screen, tissue samples were digested in an open vessel using a sulfuric acid and $\mathrm{H}_{2} \mathrm{O}_{2}$ procedure and phosphate was measured by colorimetric determination, in duplicate (Tedesco et al., 1995). The amount of $\mathrm{P}$ in the tissues samples was obtained by multiplying the content of this nutrient by the dry matter weight. Phosphorus partitioning was obtained by calculating the percentage of $\mathrm{P}$ accumulated in each part of the plant, related to the total amount of this nutrient in the plant. Some data (root dry mass and the amount of P in roots, stems, and leaves) had to be transformed (square root of the data) to meet requirements for analysis of variance, but all results are presented in their original scale of measurement. The means of oat cultivar were compared using the Scott-Knott test $(\mathrm{P}<0.05)$.

There was wide range in dry matter content for both oat cultivars and plant parts sampled. The highest dry matter values were in grain, which accumulated approximately $40 \%$ of the total biomass, while the lowest values were reported in roots and leaves (approximately $15 \%$ and $20 \%$ of total dry mass, respectively; Table 1). Cultivar grain weight ranged from 1.46 ('Afrodite') to $1.97 \mathrm{~g}$ plant $^{-1}$ ('Barbarasul'), indicating groups with lower ('Afrodite' and 'FAPA Slava') and higher grain production (other cultivars). The grain weight of the more productive cultivars was about $20 \%$ higher than the 'average' $\left(1.73 \mathrm{~g}\right.$ plant $\left.{ }^{-1}\right)$. Among the cultivars with lower grain weight, 'FAPA Slava' accumulated a lower biomass of root, stem, and leaves than 'Afrodite'. These results suggested that lower leaves biomass has limited photo-assimilate production in this source and, consequently, its transfer to the grain. However, the lower grain weight of 'Afrodite' may be due to the higher photo-assimilate accumulation on roots and vegetative structures of the plants. This cultivar stood out as accumulating more dry matter in such organs, rather than in grain (Table 1). Roots and leaves were important sink organs of photo-assimilates, and impaired grain production of 'Afrodite'. 
Table 1 -Dry matter amount $\left(\mathrm{g} \mathrm{p}^{-1}\right)^{1}$ and partitioning $(\%)$ in different parts of plant of white oat cultivars.

\begin{tabular}{|c|c|c|c|c|c|c|c|c|c|c|c|c|}
\hline \multirow[t]{2}{*}{ Cultivar } & \multicolumn{2}{|c|}{--------Root------- } & \multicolumn{2}{|c|}{-------Stem------ } & \multicolumn{2}{|c|}{------Leaves---- } & \multicolumn{2}{|c|}{-------Grain------ } & \multicolumn{2}{|c|}{ Stem+Leaves } & \multicolumn{2}{|c|}{$\begin{array}{c}\text { Stem+Leaves+ } \\
\text { Grain }\end{array}$} \\
\hline & $\left(g p^{1}\right)^{*}$ & $(\%)$ & $\left(\mathrm{g} \mathrm{p}^{-1}\right)$ & $(\%)$ & $\left(\mathrm{g} \mathrm{p}^{-1}\right)$ & $(\%)$ & $\left(\mathrm{g} \mathrm{p}^{-1}\right)$ & $(\%)$ & $\left(\mathrm{g} \mathrm{p}^{-1}\right)$ & $(\%)$ & $\left(\mathrm{g} \mathrm{p}^{-1}\right)$ & $(\%)$ \\
\hline 'URS 21' & $0.89 \mathrm{~b}$ & $19.1 \mathrm{a}$ & $1.18 \mathrm{~b}$ & $25.5^{\mathrm{ns}}$ & $0.80 \mathrm{c}$ & $17.0^{\mathrm{ns}}$ & $1.78 \mathrm{a}$ & $38.3 \mathrm{a}$ & $1.98 \mathrm{~b}$ & $42.6^{\mathrm{ns}}$ & $3.76 \mathrm{~b}$ & $80.9^{n}$ \\
\hline 'Afrodite' & $1.09 \mathrm{a}$ & $22.9 \mathrm{a}$ & $1.34 \mathrm{a}$ & 27.1 & $1.04 \mathrm{a}$ & 20.8 & $1.46 \mathrm{~b}$ & $29.2 \mathrm{~b}$ & $2.38 \mathrm{a}$ & 50.0 & $3.71 \mathrm{~b}$ & 77.1 \\
\hline $\begin{array}{l}\text { 'FAPA } \\
\text { Slava' }^{2}\end{array}$ & $0.59 \mathrm{~d}$ & $16.7 \mathrm{~b}$ & $0.91 \mathrm{c}$ & 25.0 & $0.63 \mathrm{~d}$ & 16.7 & $1.50 \mathrm{~b}$ & $41.7 \mathrm{a}$ & $1.55 \mathrm{c}$ & 41.7 & $3.05 \mathrm{c}$ & 83.3 \\
\hline 'Barbarasul' & $0.65 \mathrm{~d}$ & $12.5 \mathrm{~b}$ & $1.45 \mathrm{a}$ & 29.2 & $0.79 \mathrm{c}$ & 16.7 & $1.97 \mathrm{a}$ & $41.7 \mathrm{a}$ & $2.25 \mathrm{a}$ & 45.8 & $4.35 \mathrm{a}$ & 89.6 \\
\hline 'FAEM 007' & $0.73 \mathrm{c}$ & $15,6 \mathrm{~b}$ & $1.11 \mathrm{~b}$ & 24.4 & $0.89 \mathrm{~b}$ & 20.0 & $1.82 \mathrm{a}$ & $40.0 \mathrm{a}$ & $2.00 \mathrm{~b}$ & 44.4 & $3.82 \mathrm{~b}$ & 84.4 \\
\hline 'Ouro' & $0.77 \mathrm{c}$ & $16.3 \mathrm{~b}$ & $1.51 \mathrm{a}$ & 30.6 & $0.74 \mathrm{c}$ & 14.3 & $1.86 \mathrm{a}$ & $38.8 \mathrm{a}$ & $2.26 \mathrm{a}$ & 46.9 & $4.12 \mathrm{a}$ & 83.7 \\
\hline 'Farroupilha' & $0.65 \mathrm{~d}$ & $13.3 \mathrm{~b}$ & $1.30 \mathrm{a}$ & 28.9 & $0.83 \mathrm{c}$ & 17.8 & $1.78 \mathrm{a}$ & $40.0 \mathrm{a}$ & $2.13 \mathrm{a}$ & 46.7 & $3.91 \mathrm{a}$ & 86.7 \\
\hline 'Taura' & $0.55 \mathrm{~d}$ & $11.9 \mathrm{~b}$ & $1.28 \mathrm{a}$ & 31.0 & $0.69 \mathrm{~d}$ & 16.7 & $1.68 \mathrm{a}$ & $40.5 \mathrm{a}$ & $1.98 \mathrm{~b}$ & 47.6 & $3.66 \mathrm{~b}$ & 88.1 \\
\hline 'Average' & 0.74 & 15.6 & 1.30 & 28.9 & 0.80 & 17.8 & 1.73 & 37.8 & 2.06 & 44.4 & 3.80 & 84.4 \\
\hline 'C.V. (\%)' & 9.00 & 10.98 & 12.90 & 13.06 & 8.40 & 6.50 & 7.00 & 5.89 & 10.10 & 13.60 & 8.40 & 11.8 \\
\hline
\end{tabular}

${ }^{1}$ Gram plant ${ }^{-1}$. Data are transformed for analysis of variance, but results are presented in their original scale of measurement. Means in the same column and followed by the same letter does not differ by Scott-Knott test $(\mathrm{P}>0.05)$. ${ }^{\text {ns: }}$ No significant difference between treatments $(\mathrm{P}>0.05)$. C.V.: Coefficient of variation.

Root and grain biomass partitioning vary across cultivars, but it did not vary among the other parts of the plants (Table 1).The highest root dry matter partitioning of root biomass was in 'URS 21' and 'Afrodite' cultivars (19.1 and 22.9\%, respectively), while there was no difference among the other cultivars. Grain biomass partitioning was lower in 'Afrodite' compared with other cultivars, which showed no differences to each other.

Phosphorus content in plant parts vary across cultivars, except in grain. However, the higher contents of $\mathrm{P}$ were in grain and leaves, while the lower contents were reported in roots and stems (Table 2). 'Averaged' over cultivars, $P$ content in grain $\left(4.0 \mathrm{~g} \mathrm{~kg}^{-1}\right.$ or $\left.9.2 \mathrm{~g} \mathrm{P}_{5} \mathrm{O}_{5} \mathrm{~kg}^{-1}\right)$ is consistent with results reported by ESCOSTEGUY et al. (2014) and was similar to recommendations for oat maintenance fertilization (7.0 $\mathrm{g}_{5} \mathrm{O}_{5} \mathrm{~kg}^{-1}$ ) in southern Brazil (BONA et al., 2016). The slight difference between ours results and the recommendations for this part of the country may largely be a consequence of the cultivars, because $\mathrm{P}$ content suggested by BONA et al. (2016) was from old oat cultivars. Therefore, the 'average' grain $\mathrm{P}$ content of the cultivars (Table 2) may be used for modern oats maintenance fertilization. For practical use, this can be adjusted to $10 \mathrm{~g}_{5} \mathrm{O}_{5} \mathrm{~kg}^{-1}$ of grain. However, the 'average' $\mathrm{P}$ content in roots and stems are consistent with results reported by PARK et al. (2016) and WENDLING (2016), respectively.

As reported for the dry matter and the content of $\mathrm{P}$, the uptake and partitioning of this nutrient varied across cultivars, and in all part of the plants (Table 3). In general, the higher P uptake was accumulated in grain and decreased in leaves, stems, and roots. However, the uptake amount of $P$ reported in roots of 'Afrodite' and 'FAEM 007' was similar to the amount of this nutrient in the stems of these cultivars. Furthermore, the lowest uptake of Pin the grain was observed in 'Afrodite' $\left(6.0 \mathrm{mg} \mathrm{plant}^{-1}\right)$ and 'FAPA Slava' (5.6mg plant ${ }^{-1}$ ), which was because of the lower grain weight of these cultivars (Table 1). The effect of the grain weight on $\mathrm{P}$ requirements was also observed for the highest grain production cultivars and is because the grains' $\mathrm{P}$ content did not vary across cultivars (Table 2). In the same way, because of the lower dry matter accumulated in the stems, leaves, and grains (Table 1), 'FAPA Slava' was the cultivar with the lower $\mathrm{P}$ accumulation in these organs (Table 3 ). Results presented in tables 1 and 2 show that the amount of $\mathrm{P}$ in grain varies among oat cultivars (Table 3 ) and that the grain biomass was the most important trait for fertilization maintenance.

'Averaged' over cultivars, the higher $\mathrm{P}$ partitioning in the grain $(\sim 53 \%)$ was followed by 
Table 2 - Phosphorus content $\left(\mathrm{g} \mathrm{P} \mathrm{kg}^{-1}\right)$ and uptake amount $\left(\mathrm{g} \mathrm{P}_{2} \mathrm{O}_{5}\right.$ plant $\left.{ }^{-1}\right)$ in parts of plant of white oat cultivars.

\begin{tabular}{|c|c|c|c|c|c|c|c|c|c|}
\hline \multirow[t]{2}{*}{ Cultivar } & \multirow{2}{*}{$\begin{array}{l}\text { Root } \\
\mathrm{g} \mathrm{kg}^{-1}\end{array}$} & \multicolumn{2}{|c|}{-----------Stem-------- } & \multicolumn{2}{|c|}{---------Leaves-------- } & \multicolumn{2}{|c|}{----------Grain-------- } & \multicolumn{2}{|c|}{ Stem+Leaves + Grain } \\
\hline & & $\mathrm{g} \mathrm{kg}^{-1}$ & g plant $^{-1}$ & $\mathrm{~g} \mathrm{~kg}^{-1}$ & g plant $^{-1}$ & $\mathrm{~g} \mathrm{~kg}^{-1}$ & g plant $^{-1}$ & $\mathrm{~g} \mathrm{~kg}^{-1}$ & g plant ${ }^{-1}$ \\
\hline 'URS 21' & $1.5 \mathrm{c}$ & $1.2 \mathrm{~b}$ & $2.7 \mathrm{~b}$ & $3.2 \mathrm{c}$ & $7.3 \mathrm{c}$ & $4.1^{\mathrm{ns}}$ & $9.4^{\mathrm{ns}}$ & $8.5 \mathrm{~b}$ & $19.6 \mathrm{~b}$ \\
\hline 'Afrodite' & $1.6 \mathrm{~b}$ & $1.4 \mathrm{a}$ & $3.2 \mathrm{a}$ & $3.5 \mathrm{~b}$ & $8.0 \mathrm{~b}$ & 4.1 & 9.4 & $9.0 \mathrm{a}$ & $20.7 \mathrm{a}$ \\
\hline 'FAPA Slava' & $1.3 \mathrm{~d}$ & $1.3 \mathrm{~b}$ & $3.0 \mathrm{~b}$ & $3.0 \mathrm{~d}$ & $7.0 \mathrm{~d}$ & 3.7 & 8.5 & $8.0 \mathrm{~b}$ & $18.3 \mathrm{~b}$ \\
\hline 'Barbarasul' & $1.8 \mathrm{a}$ & $1.3 \mathrm{~b}$ & $3.0 \mathrm{~b}$ & $4.0 \mathrm{a}$ & $9.2 \mathrm{a}$ & 3.9 & 8.9 & $9.1 \mathrm{a}$ & $21.0 \mathrm{a}$ \\
\hline 'FAEM 007' & $1.7 \mathrm{~b}$ & $1.2 \mathrm{~b}$ & $2.7 \mathrm{~b}$ & $3.7 \mathrm{~b}$ & $8.5 \mathrm{~b}$ & 3.8 & 8.7 & $8.7 \mathrm{~b}$ & $19.9 \mathrm{~b}$ \\
\hline 'Ouro’' & $1.6 \mathrm{~b}$ & $1.3 \mathrm{~b}$ & $3.0 \mathrm{~b}$ & $3.6 \mathrm{~b}$ & $8.2 \mathrm{~b}$ & 4.4 & 10.0 & $9.3 \mathrm{a}$ & $21.3 \mathrm{a}$ \\
\hline 'Farroupilha' & $1.4 \mathrm{c}$ & $1.4 \mathrm{a}$ & $3.2 \mathrm{a}$ & $3.1 \mathrm{c}$ & $7.0 \mathrm{c}$ & 4.6 & 10.5 & $9.1 \mathrm{a}$ & $20.9 \mathrm{a}$ \\
\hline 'Taura' & $1.4 \mathrm{c}$ & $1.1 \mathrm{~b}$ & $2.5 \mathrm{~b}$ & $3.2 \mathrm{c}$ & $7.3 \mathrm{c}$ & 4.0 & 9.1 & $8.3 \mathrm{~b}$ & $19.2 \mathrm{~b}$ \\
\hline 'Average' & 1.5 & 1.3 & 2.9 & 3.4 & 7.8 & 4.0 & 9.2 & 8.7 & 19.9 \\
\hline 'C.V. (\%)' & 5.7 & 7.9 & 7.3 & 2.0 & 5.1 & 11.8 & 12.1 & 9.98 & 9.01 \\
\hline
\end{tabular}

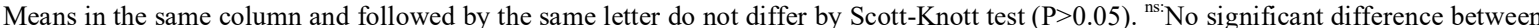
treatments $(\mathrm{P}>0.05)$. C.V.: Coefficient of variation.

$\mathrm{P}$ in the leaves $(\sim 25 \%)$, and both stems and roots $(\sim 10 \%$; Table 3$)$. Nearly $40 \%$ ('FAPA Slava') to $60 \%$ ('Ouro') of the $\mathrm{P}$ absorbed by the plant was in the grain. These results indicated that this part of the plant is the major P sink, as is typically found in annual cereal crops. A large amount (50\%-70\%) of the total $\mathrm{P}$ in cereal grains is phytic acid and it is used as source of energy by the embryo during the seed germination. This physiological role of $\mathrm{P}$ explains why this nutrient partitioning is large located in the grains (GUIMARÃES et al., 2016; TAIZ \& ZEIGER, 2017). Significant differences of $P$ partitioning among the oats varieties also were found in the roots and leaves. In the roots, $\mathrm{P}$ partitioning ranged from $7 \%$ ('Farroupilha' and 'Taura') to 13\% ('Afrodite'; Table 3). Additionally, there was less cultivar variability for $\mathrm{P}$ partitioning in the stem compared with the other parts of the plant.

Results in tables 1 and 3 show that the amounts of $\mathrm{P}$ uptake and cycling change across

Table 3 - Amount of phosphorus uptake $\left(\mathrm{P}, \mathrm{mg} \text { plant }^{-1}\right)^{*}$ and partitioning $(\%)$ in different parts of plant of white oat cultivars.

\begin{tabular}{|c|c|c|c|c|c|c|c|c|c|c|c|c|}
\hline \multirow[t]{2}{*}{ Cultivar } & \multicolumn{2}{|c|}{-------Root----- } & \multicolumn{2}{|c|}{-------Stem----- } & \multicolumn{2}{|c|}{$\begin{array}{c}\text {-----Leaves---- } \\
-\end{array}$} & \multicolumn{2}{|c|}{-------Grain----- } & \multicolumn{2}{|c|}{ Stem+Leaves } & \multicolumn{2}{|c|}{ Stem + Leaves + Grain } \\
\hline & $\mathrm{P}$ & $(\%)$ & $\mathrm{P}$ & $(\%)$ & $\mathrm{P}^{*}$ & $(\%)$ & $\mathrm{P}$ & $(\%)$ & $\mathrm{P}$ & $(\%)$ & $\mathrm{P}$ & $(\%)$ \\
\hline 'URS 21' & $1.3 \mathrm{~b}$ & $10.2 \mathrm{~b}$ & $1.5 \mathrm{~b}$ & $11.5 \mathrm{~b}$ & $2.6 \mathrm{c}$ & $20.3 \mathrm{c}$ & $7.4 \mathrm{a}$ & $57.7 \mathrm{a}$ & $4.3 \mathrm{~b}$ & $31.8 \mathrm{~b}$ & $11.7 \mathrm{~b}$ & $89.7 \mathrm{c}$ \\
\hline 'Afrodite' & $1.7 \mathrm{a}$ & $13.0 \mathrm{a}$ & $1.9 \mathrm{a}$ & $14.6 \mathrm{a}$ & $3.6 \mathrm{a}$ & $27.4 \mathrm{a}$ & $6.0 \mathrm{~b}$ & $45.0 \mathrm{~b}$ & $4.6 \mathrm{a}$ & $42.0 \mathrm{a}$ & $11.6 \mathrm{~b}$ & $87.1 \mathrm{~b}$ \\
\hline $\begin{array}{l}\text { 'FAPA } \\
\text { Slava' }\end{array}$ & $0.8 \mathrm{~d}$ & $8.4 \mathrm{c}$ & $1.2 \mathrm{~b}$ & $8.6 b$ & $1.9 \mathrm{e}$ & $19.5 \mathrm{c}$ & $5.6 \mathrm{~b}$ & $40.2 \mathrm{c}$ & $3.4 \mathrm{c}$ & $32.2 b$ & $8.7 \mathrm{c}$ & $62.2 \mathrm{~d}$ \\
\hline 'Barbarasul' & $1.2 b$ & $8.4 \mathrm{c}$ & $1.8 \mathrm{a}$ & $13.1 \mathrm{~b}$ & $3.2 b$ & $23.0 \mathrm{~b}$ & $7.7 \mathrm{a}$ & $55.2 \mathrm{a}$ & $4.7 \mathrm{a}$ & $36.4 a$ & $12.8 \mathrm{a}$ & $91.4 b$ \\
\hline 'FAEM 007' & $1.2 b$ & $8.7 \mathrm{c}$ & $1.3 \mathrm{a}$ & $10.0 \mathrm{~b}$ & $3.3 b$ & $25.2 \mathrm{a}$ & $6.9 \mathrm{a}$ & $49.2 b$ & $4.5 \mathrm{a}$ & $36.5 \mathrm{a}$ & $11.6 b$ & $82.2 b$ \\
\hline 'Ouro' & $1.3 \mathrm{~b}$ & $9.5 \mathrm{c}$ & $2.0 \mathrm{a}$ & $15.0 \mathrm{a}$ & $2.7 \mathrm{c}$ & $20.1 \mathrm{c}$ & $8.1 \mathrm{a}$ & $61.3 \mathrm{a}$ & $2.7 \mathrm{~d}$ & $33.7 b$ & $12.8 \mathrm{a}$ & $96.5 b$ \\
\hline 'Farroupilha' & $0.9 \mathrm{c}$ & $6.9 \mathrm{~d}$ & $1.9 \mathrm{a}$ & $14.0 \mathrm{a}$ & $2.6 \mathrm{c}$ & $19.4 \mathrm{c}$ & $7.8 \mathrm{a}$ & $58.0 \mathrm{a}$ & $2.8 \mathrm{~d}$ & $34.0 \mathrm{~b}$ & $12.3 \mathrm{a}$ & $91.7 \mathrm{a}$ \\
\hline 'Taura' & $0.8 \mathrm{~d}$ & $7.0 \mathrm{~d}$ & $1.5 \mathrm{~b}$ & $13.2 \mathrm{a}$ & $2.2 \mathrm{~d}$ & $19.5 \mathrm{c}$ & $6.9 a$ & $60.0 \mathrm{a}$ & $3.4 \mathrm{c}$ & $33.1 \mathrm{~b}$ & $10.6 b$ & $92.8 \mathrm{a}$ \\
\hline 'Average' & 1.1 & 9.5 & 1.6 & 10.7 & 2.8 & 24.3 & 7.0 & 53.3 & 3.8 & 34.9 & 11.5 & 86.7 \\
\hline 'C.V. (\%)' & 5.60 & 9.50 & 18.0 & 10.2 & 2.00 & 16.00 & 15.80 & 8.90 & 6.20 & 10.30 & 7.21 & 1.56 \\
\hline
\end{tabular}

${ }^{*}$ Data are transformed for analysis of variance, but results are presented in their original scale of measurement. Means in the same column and followed by the same letter do not differ by Scott-Knott test $(\mathrm{P}>0.05)$. C.V.: Coefficient of variation.

Ciência Rural, v.49, n.2, 2019. 
cultivars, besides the type of use of oat (such as grain, pasture, silage, or cover crop). Hence, the amount of $\mathrm{P}$ indicated as a maintenance fertilization also may change with the oat cultivar. In southern Brazil, grain production is the most common agricultural use of oat. Because our results show that $\mathrm{P}$ partitioning is more concentrated in grain, a higher rate of $\mathrm{P}$ as maintenance fertilization will be needed first in oat silage, and second in grain oat production. Then, as indicated by the results shown in Table 3, for these uses, cultivars 'URS 21', 'Barbarasul', 'FAEM 007', 'Ouro', 'Farroupilha', and 'Taura' require the higher rates of $\mathrm{P}$, while 'Afrodite' and 'FAPA Slava' require the lower rate. Extrapolating the results in Tables 1 and 2 to 1.0 ha, the amount of exported $\mathrm{P}$ in the grain would range from 40 ('Afrodite' and 'FAPA Slava') to $55 \mathrm{~kg} \mathrm{P}_{2} \mathrm{O}_{5}$ ha $^{-1}$ (other cultivars). This difference of the maintenance fertilization rate $\left(15 \mathrm{~kg} \mathrm{P}_{2} \mathrm{O}_{5} \mathrm{ha}^{-1}\right)$ between high and low grain yield potential cultivars can be economically important depending on the scale of production.

When the oat cultivars are used as forage, maintenance fertilization increases in the following order: 'Ouro' and 'Farroupilha' <'FAPA Slava' e 'Taura'<'URS 21'<'Afrodite', 'Barbarasul' and 'FAEM 007' (Table 3). The higher stem and leave biomasses were in 'Afrodite' (Table 1), as were the higher amounts of exported $\mathrm{P}$ in these parts of the plant $(11.2 \mathrm{~g}$ $\mathrm{P}_{2} \mathrm{O}_{5} \mathrm{~kg}^{-1}$; Table 2). When the cultivars are used as silage, the maintenance fertilization rates are higher for 'Barbarasul', 'Ouro' and 'Farroupilha', while 'FAPA Slava' has a lower rate. Cultivar 'Afrodite' stood out for its high root and leaf biomass production (Table 2) and high $\mathrm{P}$ accumulated in these parts of plant (Table 3 ). Therefore, the amount of $\mathrm{P}$ cycling is higher in this cultivar, which can accumulate15 $\mathrm{g} \mathrm{P}_{2} \mathrm{O}_{5} \mathrm{~kg}^{-1}$ when used as cover crop. Additionally, this cultivar requires a lower P maintenance fertilization rate.

Among the cultivars with the highest grain weight ('URS 21', 'Barbarasul', 'FAEM 007', 'Ouro', 'Farroupilha', and 'Taura'), the lowest P requirements in the stem, leaves, and grain were in 'URS 21', 'FAEM 007', and 'Taura' (Table 3). This indicated that the latter cultivars are more efficient for grain production; although the difference between cultivar groups with high and low requirements was small (1.0 to $2.0 \mathrm{~g} \mathrm{P}_{2} \mathrm{O}_{5} \mathrm{~kg}^{-1}$ ). Stem and leaf biomasses were higher in 'Ouro' and 'Farroupilha' compared with the cultivar 'averages' (Table 1), but the P requirement of these cultivars was lower than in other cultivars (Table 3 ). This also indicates that the latter cultivars are more efficient for grain production; although, the amount of P varied slightly (1.0 to $2.0 \mathrm{~g}$
$\mathrm{P}_{2} \mathrm{O}_{5} \mathrm{~kg}^{-1}$ ) between the cultivars with high and low requirements. The highest plant biomass was found in 'Barbarasul', 'Ouro', and 'Farroupilha' (4.35, 4.12, and 3.91 $\mathrm{g} \mathrm{plant}^{-1}$, respectively), which exported nearby $9.0 \mathrm{~g} \mathrm{P}_{2} \mathrm{O}_{5} \mathrm{~kg}^{-1}$. These cultivars, besides 'Afrodite', exported a lower amount of $\mathrm{P}$ per biomass. Therefore, these cultivars are more efficient in P use for biomass and; consequently, for silage.

Phosphorus requirements and partitioning in roots, stems, leaves, and grains of white oat vary among cultivar. This indicates that genotype, beside the agricultural use of oat (such as grain, pasture, silage, and cover crop) is necessary to improve the $\mathrm{P}$ maintenance fertilization rate of this crop.

\section{ACKNOWLEDGEMENTS}

We thank Coordenação de Aperfeiçoamento de Pessoal de Nível Superior (CAPES) for scholarship and Fundação de Amparo a Pesquisa do Estado do Rio Grande do Sul (Edital Fapergs/CNPq 12/2014 - PRONEX), process number 16/0484-6, for research funding.

\section{DECLARATION OF CONFLICTING INTERESTS}

The authors declare no conflict of interest. The founding sponsors had no role in the design of the study; in the collection, analyses, or interpretation of data; in the writing of the manuscript, and in the decision to publish the results.

\section{AUTHORS' CONTRIBUTIONS}

The authors contributed equally to the manuscript.

\section{REFERENCES}

BONA, F.D. etal. In. COMISSÃO DE QUÍMICA E FERTILIDADE DO SOLO-RS/SC. Manual de calagem e adubação para os estados do Rio Grande do Sul e de Santa Catarina. 11 $11^{\mathrm{a}}$.ed. SBCS-NRS, Frederico Westphalen, 2016, p.101-134.

COMISSÃO DE QUÍMICA E FERTILIDADE DO SOLO-RS/ SC. Manual de adubação e de calagem para os estados do Rio Grande do Sul e de Santa Catarina. $10^{\text {a }}$.ed. SBCS-NRS, Porto Alegre, 2004, p.394.

ESCOSTEGUY, P.A.V. et al. In. COMISSÃO BRASILEIRA DE PESQUISA DE AVEIA. Indicações técnicas para a cultura da aveia. UPF, Passo Fundo, 2014, p.24-43.

FIORIN, J.E.; LIMA, L.O.C. In. SOCIEDADE BRASILEIRA DE CIÊNCIA DO SOLO (SBCS). Manual de calagem e adubação para os estados do Rio Grande do Sul e de Santa Catarina. $11^{\mathrm{a}}$.ed. SBCS - NÚCLEO REGIONAL SUL - COMISSÃO DE QUÍMICA E FERTILIDADE DO SOLO - RS/SC, Frederico Westphalen, 2016, p.135-154.

GUIMARÃES, P.R. et al. Brune black oat (Avena strigose Schreb.) growth and root anatomical changes in sandy soil with different

Ciência Rural, v.49, n.2, 2019. 
copper and phosphorus concentrations. Water Air Soil Pollution, v.227, p.192-196, 2016. Available from: <https://link.springer. com/article/10.1007/s11270-016-2900-5>. Accessed: Feb. 10, 2017. doi10.1007/s11270-016-2900-5.

NAKAGAWA, J.; ROSELEM, C.A. Nutrient concentration in leaves and grains of black oataffected by phosphorus and potassium fertilization. Bragantia, v.64, p.441-445, 2005. Available from: $<$ http://www.scielo.br/pdf/brag/v64n3/26438.pdf > . Accessed: Feb. $15,2017$.

NAKAGAWA, J. et al. Nutrient concentrations in the flag leaf and grains of black-oat affected by phosphate and potassium fertilization. Ciências Agrárias, v.30, p.833-840, 2009. Available from: <http:// www.uel.br/revistas/uel/index.php/semagrarias/article/view/4078>. Accessed: Mar. 18, 2016. doi.10.5433/1679-0359.

PARK, N.D. et al. Wood pellet fly ash and bottom ash as an effective liming agent and nutrient source for rye grass (Lolium perenne $\mathrm{L}$.) and oats (Avena sativa). Chemosphere, v. 86, p.427-432, 2016. Available from: $<$ http://www.sciencedirect.com/science/article/pii/ S0045653511012288>. Accessed: Mar. 29 de 2016. doi:10.1016/j. chemosphere.2011.10.052.

SILVA, A. et al. Phosphorus uptake efficiency, root morphology and architecture in Brazilian wheat cultivars. Journal of Radio
Analytical and Nuclear Chemistry, v.305, p.231, 2015. Available from: <https://link.springer.com/article/10.1007/s10967-015-42823>.Accessed: Jan. 8, 2017. doi: 10.1007/s10967-015-4282-3.

SORATTO, R.P.; CRUSCIOL, C.A.C. Nutrition and grain yield of black oat as affected by surface application of lime and phosphogypsum at the establishment of no-tillage system. Revista Brasileira de Ciência do Solo, v.32, p.715-725, 2008. Available from: $\quad<$ http://www.redalyc.org/html/1802/180214228026/>. Accessed: Feb. 15, 2017.

TAIZ, L.; ZEIGER, E. Fisiologia Vegetal, 6ª .ed., Artmed, 2017, p.888.

TEDESCO, M.J. et al. Análise de solo, plantas e outros materiais. Ed. Universidade Federal do Rio Grande do Sul, 1995, p.174. (Boletim técnico, 5).

USDA - Soil Survey Staff. Keys to soil taxonomy. 12 ed., Washington: USDA-Natural Resources Conservation Service, 2014. $871 \mathrm{p}$.

WENDLING, M. et al. Influence of root and leaf traits on the uptake of nutrients in cover crops. Plant and Soil, v.1007, p.1104-2974, 2016. Available from: <https://link.springer.com/ article/10.1007/s11104-016-2974-2>. Accessed: Feb. 12, 2017. doi: 10.1007/s11104-016-2974-2. 